\title{
JIM “UNDER A CLOUD”: THE CAREER OF A LEITMOTIF
}

\author{
Nic Panagopoulos \\ National \& Kapodistrian University of Athens
}

\begin{abstract}
The present paper begins by arguing that, unlike the omnipresent phrase "one of us" in Lord Jim which has two easily identifiable primary sources, namely Genesis 3:22 and Poetics II, the source of the related poetic leitmotif which imagines grief or shame as a clouded sky is multiple and protean. What Conrad called "the common expressions, "under a cloud"" (LJ 259) is shown to have travelled through such grand narratives as Homer's Iliad (750-700 BC), Sophocles' Antigone (442441 BC), and Euripides' Hippolytus (428 BC), before gracing the pages of Lord Jim. In the shame culture of epic, the clouded-sky motif is identified as signaling the warrior's rising ire through the pathetic fallacy. In tragedy, on the other hand, the same motif in conjunction with the convention of the theatrical mask is said to signify the opaqueness and inaccessibility of the human psyche which necessitates the construction of identity while facilitating the production of scapegoats. However, in keeping with the anti-Gnostic pessimism that Conrad shares with the Greek tragedians, Lord Jim presents the ontological and moral fog surrounding the protagonist as a blessing in disguise since, as Oedipus' fate illustrates, there may be more danger finally in being understood than in being misunderstood. Thus, given that Jim is "one of us", his clouded countenance-akin to a mask shielding an actor's face from himself as much as from the audience-is presented by the novel as humanity's last line of defense against tragic knowledge.
\end{abstract}

Keywords: Lord Jim, "under a cloud", intertext, Homeric epic, shame culture, kleos, poetic formulas, Greek tragedy, theatrical mask, construction of identity, recognition, pessimism, tragic knowledge

The idiomatic phrase "under a cloud," primarily meaning "under suspicion, discredited" (OED), but also 'difficult to see/understand' runs throughout Lord Jim (1900) like a poetic refrain suggestively establishing the novel's main concerns through nuanced repetition. The image itself is self-reflexive in its ontological and moral ambiguity, potentially denoting an object in half-light, shadow, or even darkness: the "chiaroscuro effect" (Watt 98) or "play of shadows" (Najder 81) is a mainstay of Conradian aesthetics. Conrad first highlights the clouded-sky motif in the Author's Note to the novel: 
One sunny morning, in the commonplace surroundings of an Eastern roadstead, I saw his form pass by - appealing — significant — under a cloud... It was for me, with all the sympathy of which I was capable, to seek fit words for his meaning. He was 'one of us.' ( $L J 320$ )

While directly appealing to the reader's solidarity on behalf of the Patna's most "symbolic" ( $L J$ 203) renegade, the authorial yoking of the phrases "under a cloud" and "one of us" encapsulates the entire narrative strategy of Lord Jim. Placed in fruitful interplay, the two central leitmotifs of the novel produce a wide range of interrelated but also antithetical meanings; e.g. Jim is "one of us" (whoever 'we' may be) both because he is "under a cloud" and despite being "under a cloud." The protagonist also seems to inhabit an epistemological mist or fog, recalling the famous atmospheric metaphor found in Dickens which is used to indict the same lack of understanding in Victorian society that Marlow tries to counteract in his audience with regard to Jim. Although the phrase "one of us" can be bent into virtually any shape in Lord Jim, it has two, easily identifiable, primary sources. The first is Genesis 3:22, where the Elohim say of the fallen Adam: "Behold, the man has become as one of us, to know good and evil" (Najder 86); and the second is Book II of Aristotle's Poetics, where the generally superior characters of tragedy are described as also having to be "like us" (1386a) to encourage identification and, by extension, pity (Batchelor 181).

On the other hand, the pedigree of what Marlow calls "the common expressions, "under a cloud" ( $L J$ 259) is multiple and protean. Naturally, no single author can be credited with such an archetypal motif that imagines grief or shame as a clouded sky and which doubtlessly abounds in folk narratives of all cultures. Nevertheless, the humble clouded-sky motif can be shown to have travelled through such grand narratives as Homer's Iliad (750-700 BC), Sophocles' Antigone (442-441 BC), and Euripides' Hippolytus (428 BC) before gracing the pages of Lord Jim. Although, even within the context of Conrad's novel, the phrase "under a cloud" fluctuates semantically — changing as many hues as Jim's embarrassed face - the aim of this paper is not to trace its intertextual variations but its transtextual career which appears to span European literary production from earliest antiquity to late modernity. Related thematic parallels will also be drawn between these prior texts and Lord Jim that suggest a common literary but also philosophical tradition to which Conrad's work, it is argued, contributes significantly.

Without the Iliad there could never have been a Jim. Homer's seminal masterpiece, the epic that launched a thousand texts, is not only the inspiration behind the "light holiday literature" $(L J 7)$ that makes Jim want to be like "a hero in a book" $(L J 8)$, but also the poetic source of his warrior code, so out of place in the mercenary world of steam in which the story unfolds. ${ }^{1}$ Homeric heroes perform exclusively in the public

\footnotetext{
${ }^{1}$ Other critics who have noted the importance of the ancient ideal of honour for Jim's character include John Batchelor and Zdzisław Najder. See J. Batchelor, Lord Jim, London: Unwin Hyman, 1988; Z. Najder,
} 
arena, competing before the eyes of other men for wealth and glory, but most importantly for kleos, the fame that stays with one after death. It could be argued that this kind of fame is Jim's more or less subconscious motive from the start and the ideal of service implicit in the maritime code constitutes for him a necessary detour, a cumbersome means of achieving this most prized of ends - hence his essential disregard for his seaman's certificate when it is cancelled. As the Patusan section of the book illustrates, Jim was never a sailor ${ }^{2}$ or a leader of men but a warrior at heart.

Epic elements in Conrad's work are usually identified in the companion piece, Heart of Darkness, ${ }^{3}$ but the affinities between the Iliad and Lord Jim are considerable, not least because of the marked oral quality of Jim's story which was imagined by Conrad as one long monologue with the chapter divisions as pauses for rest (Tadié 31). The crucial event in Homer's version of the Trojan War is Agamemnon's stealing of Achilles' Trojan concubine, Briseis, which sparks off a vicious feud in the Greek camp, resulting in the hero's refusal to further participate in the war until his adopted brother, Patroclus, is tragically killed fighting in his place. Just like Jim who first abandons his duty on the Patna and subsequently places his personal honour above the good of his community in Patusan, Achilles (described by Aristotle as "both a good man and a paradigm of obstinacy" [Poetics 1454b]) ends up harming the very people he ought to have protected. Honourable and shameful behaviour is mixed in equal doses, however, since- like Jim who does not shy away from the consequences of his actions after the slaughter of Dain Waris' party-Achilles decides to rejoin the fray and take revenge for Patroclus' death even though he knows it will ultimately bring about his own demise. Moreover, there is a tearful reconciliation scene between arch enemies in Book XXIV of the Iliad where Priam confronts the slayer of his sons and wins Achilles' sympathy by reminding him of their common mortality. As Gentleman Brown says in a comparable recognition scene between him and his antagonist, "Let us agree... that we are both dead men, and let us talk on that basis, as equals. We are all equal before death" (LJ 291). Jim's behaviour during this scene similarly affirms that there is more to life than revenge and more to being a man than killing other men, but Brown sees himself as a hero in quite a different book.

Turning to the clouded-sky motif, this first appears in Book XVII of the Iliad which relates the furious vying between the Trojans and the Greeks for the body of the fallen Patroclus. The fact that Patroclus was wearing Achilles armour when he was killed raises the stakes because the spoils of war in Homer's world did not only consist of captured concubines and looted treasure, but also the bodies and armour of illustrious enemies. The passage in question goes as follows:

\footnotetext{
"Lord Jim, a Romantic Tragedy of Honour" [in:] idem, Conrad in Perspective: Essays on Art and Fidelity, Cambridge: Cambridge UP, 1997.

${ }^{2}$ There may be an autobiographical element here. As Batchelor following Najder claims, "there is a sense in which [Conrad] can be said to have hated the sea throughout his sailing career," p. 23.

${ }^{3}$ See T. Bowers, "Conrad's Aeneid: Heart of Darkness and the Classical Epic," Conradiana 2006, vol. 38(2), pp. 115-142; see also, S. Ray, "Marlow(e)'s Africa: Postcolonial Queenship in Conrad's Heart of Darkness and Marlowe's Dido, Queen of Carthage," Conradiana 2006, vol. 38(2), pp. 143-161.
} 
But now Apollo stood by Hector and urged him on... 'Hector, what Greek will ever fear you again if you let yourself be scared by Menelaus, who has been a soft touch so far? But now he has come and lifted the dead man on his own and killed your loyal friend Podes, a brave man in the front line.' So he spoke, and a black cloud of grief descended on Hector. He advanced through the ranks bronze armour glistening (Iliad 17.586-592)

The first thing to note about this passage is its momentum: no sooner is Hector's countenance clouded, than he springs into action. The heroic temper cannot abide being "under a cloud" for long but must regain honour without delay, or die trying. Jim may feel a similar urgency to clear his brow after the Patna debacle, but the first part of the novel hinges on the fact that modern life does not provide the same opportunities for glory that Homer's heroes enjoyed, so every day Jim spends in disgrace, merely keeping body and soul together, is for him a day of torment: the ethos is the same even if the cultural milieu is very different. Before he establishes himself in Patusan, Jim - like the proverbial fish out of water-is a manqué epic hero consciously playing in a "farce" ( $L J 81)$.

Secondly, in keeping with the classical warrior code that depended primarily on the judgment of one's peers rather than any internalized sense of self-worth, Apollo functions in the above passage as the voice of shame, chiding Hector for losing possession of Patroclus' body. As with Conrad's hero who seems to have "no interiority" (Ambrosini 67) other than what Marlow projects onto him, Hector's shame is conveyed through another character's speech, since Apollo impersonates one of the combatants at this point to egg his favourite on. Akin to the pathetic fallacy that derives from this technique, emotional exposition in epic is typically assisted by atmospheric effects and images that heighten the drama while conveying the natural and divine forces framing the human action. The weather is a crucial factor in war as at sea, but Conrad's comparable use of the clouded-sky motif to represent Jim's "acute consciousness of lost honour" (LJ 320) appears deliberately anachronistic, not only vis $a$ vis the protagonist's old-world morality, but also in the image's allusion to extrahuman elements that modernity was in the process of expunging from its cultural pallet. One could say that Conrad is bewailing the loss of the ancient ideal of honour while imitating the technique of epic, just as Lord Jim and the Youth trilogy as a whole constitutes a lament for the old maritime tradition and innocence of sailing ships.

An indispensible feature of the Greek oral tradition on which Homeric epic is based were standard phrases, sentences, and themes that had been refined over the centuries and constituted the stock and trade of ancient bards. Without these readymade "formulas" (Hammond 10), as they are called, a prolonged epics such as the Iliad could not have been written, not only because of the difficulties of sustaining the metre over some 15,000 lines, but also for structural reasons. Following its foray in the Iliad, the clouded-sky motif or "formula" continued its journey through European letters, passing from Homer to the Greek dramatists that inherited the epic tradition and developed from it the genre of tragedy in $5^{\text {th }}$ Century BC Athens. Indeed, the Iliad, in its sustained exploration of one man's uncompromising stance on a partial moral principle to the point of death, is in many ways the world's first tragedy (Jones xxxiv). 
II

Our next stop is Sophocles' Antigone, estimated to have been written some two and half to three centuries after the Iliad, but telling essentially the same tragic story of a character whose pride and moral perfectionism lead her to embrace a glorious death in preference to what she sees as an ignominious life. ${ }^{4}$ As with Jim and Achilles, the desire for posthumous glory also constitutes Antigone's ruling passion - a passion all the more challenging to societal norms given the fact that she is a woman. Moreover, Antigone's obsession with the decomposing body of her vanquished brother, Polyneices, and the burial rites which are his due are clearly intended to represent the very definition of the word "morbid" - the same word which Conrad defends Jim against in the Author's Note. Yet, in preferring to marry Hades (A 806-16, 893) rather than her intended, Antigone is quite likely the inspiration for Conrad's image of Jim as someone who "goes away from a living woman to celebrate his pitiless wedding with a shadowy ideal of conduct" ( $L J 318)$. Jim and Antigone refuse to be "one of us" if that means being "a type of wide commonness" ( $L J 320$ ); they will not be communally included if the price is moral compromise.

Paradoxically, although Antigone is consistently associated with death and the darkness of the underworld to the point of being buried alive in the cave which houses Polyneices' corpse, it is her sister, Ismene, to whom the clouded-sky motif is attached in the play. It is as if, by appearing "under a cloud," Ismene is showing solidarity to Antigone by partaking of the darkened state soon to befall her beloved sister. The relevant passage spoken by the Chorus goes as follows:

\section{And lo! Ismene at the gates \\ Shedding tears of sisterly love, \\ A cloud over her brows \\ Disfigures her flushed face \\ Bedewing her fair cheek.}

(Antigone 526-530, my translation)

This is the most lyrical of all the uses of the clouded-sky motif in our selection: the conceit of the cloud producing dew on the character's face is set off by the archetypal coupling of fire and ice implicit in the image of Ismene's blood rushing to her face on account of her weeping (Smead 179). Ismene's character acts as a foil to Antigone's in Sophocles' version of the myth, hence her inability to control her emotions in this scene which contrasts powerfully with her sister's hard-faced defiance of Creon. Although Ismene is of the same class as Antigone, her cautious attitude associates her with the low-life messenger who conveys the news of Antigone's insubor-

${ }^{4}$ Essays which have, in passing, connected Antigone with Lord Jim include J. Paccaud-Huguet, "The Sublime Object of Lord Jim," L'Epoque Conradienne 2004, vol. 30, p. 156; B. J. Paris, Bargains with Fate: Psychological Crises and Conflicts in Shakespeare and His Plays, foreword by Th. I. Rubin, New Brunswick: Transaction Publishers, 2009, p. 3; and S. Burke, The Ethics of Writing: Authorship and Legacy in Plato and Nietzsche, Edinburgh: Edinburgh UP, 2008, p. 39. 
dination, visibly fearing for his life. In Greek drama there was a clear distinction between the noble families whose tragic story was being related and the socially inferior but "luckier" supporting characters around them (Griffith 7). Similarly, in Lord Jim as in Heart of Darkness, Marlow's bourgeois pragmatism serves to frame and set off Jim's and Kurtz' aristocratic idealism. Like Ismene, Marlow survives by following the dictates of reason and the Apollonian dictum "nothing to excess," but no great poems will be written in his honour and he will not obtain kleos after his death. Inversely, Jim, like Antigone, is uncompromising and irrational, but he is said to attain "greatness as genuine as any man ever achieved" ( $L J 187)$. Although Jim's achievements in Patusan are bracketed and qualified by Conrad, reflecting the far more skeptical cultural climate of modernity, Lord Jim attempts to revive the moral distinction between high-born and lowly characters, so fundamental to ancient tragedy. ${ }^{5}$ Despite Jim's humble origins and his cowardly behaviour in the first part of the novel, the heroism he shows in the second part associates him with nobility in the mind of his adopted community. He thereby gains the necessary social status, symbolized by his honourary title, to die tragically, that is, significantly.

Given the tradition of mask-wearing ${ }^{6}$ on the Greek stage and the classical notion of character as public moral disposition (ethos) rather than private psychological potential, if a character did not express him/herself verbally, someone else on stage was assigned the task of externalizing their emotional state. By placing Jim consistently "under a cloud" and filling in the gaps in our understanding of the protagonist through second opinion, Conrad does something very similar to the classical dramatist who masks an actor's face and encourages the audience to imagine what lies beneath using choral commentary. A recent article suggests that Marlow functions very much like the chorus of a Greek tragedy in Lord Jim (Ambrosini 54); however, it would be more accurate to say that he is the leader of the chorus, or "choragos," since virtually every character in the novel plays the role of internal audience, offering their commentary on the protagonist's character. The main difference is that Conrad's modern chorus is made up of isolated individuals, each with his own private perspective, rather than a classical community of fellow citizens judging and speaking as one man or woman. ${ }^{8}$

In the above passage from Antigone, the Chorus, acting as mediator between Ismene and the audience, assumes that her clouded countenance expresses sisterly affection. However, the fact that the Chorus consists of Theban elders who, although representative of the average theatregoer in Sophocles' time, are by gender, status,

${ }^{5}$ This relates to Aristotle's spoudaios-favlos dichotomy. See N. Panagopoulos, "Conrad's Poetics: An Aristotelian Reading of Heart of Darkness," L'Epoque Conradienne 2015-2016, vol. 40, pp. 137-144.

${ }^{6}$ It should be noted that Polish Romantic drama often incorporated conventions from the ancient Greek stage, such as choruses, masks, and even the elevated shoes, or "buskins," worn by actors to give them a larger-than-life appearance (e.g. Juliusz Słowacki's Kordian). I am indebted to Karol Samsel for this information.

${ }^{7}$ See H. G. Liddell, R. Scott, A Greek-English Lexicon: A Supplement, $9^{\text {th }}$ Edition, eds. E. A. Barker et al., Oxford: Oxford UP, 1968, p. 1998.

${ }^{8}$ For this theme, see W. Deresiewicz, "Lord Jim and the Transformation of Community," Raritan 2000, vol. 20(2), p. 105, pp. 71-105. 
and experience very different from Ismene renders their assessment potentially unreliable. Until Ismene speaks, her actual feelings cannot be ascertained. This is a kind of Schrödinger's-cat situation in which the mysterious feline is both alive and dead until the box is opened. A similar ambivalence is to be found in Jim's clouded countenance which the narrative suggests could signify either shame or guilt. Marlow would like to read the proverbial cloud on Jim's brow as a sign of the young sailor's guilt for having broken the unwritten code of the sea. However, when the master mariner discovers that Jim's opaque countenance is actually communicative of shame, since Jim only had dealings with himself, instead of clarifying the issue for his audience, he presents the young outlaw as essentially unreadable, metaphorically closing the box again. Indeed, Marlow's mystifying strategy in the novel - the whole rhetoric of clouds and mist and fog as applied to Jim — can be seen as a species of colonization in which the other is misrepresented and linguistically appropriated by someone with vested interests. Adapting the words of Said, "if [Jim] could represent himself, he would; since he cannot, [Marlow] does the job..., and bad luck for [poor Jim]" (Orientalism 21).

However, the 'real' or 'inner' Jim - the Jim 'out of the cloud', as it were-is represented as unrepresentable for more than political reasons. Implicit in theatrical conventions is the constructedness of identity due to the fact that actors adopt fictional personas on stage in a way which reflects the social roles played by people in real life. Thus, if we step back slightly from the scene in which Ismene is described weeping, we realize that all its constituents - the mythical figure conveyed by the mask, her clouded countenance, the interpretation given by the Chorus - are entirely and selfconsciously fictitious. While we are encouraged to question the objectivity of the Chorus in Antigone more and more as the play progresses, Lord Jim raises the problem of mediation even more starkly. Although a character in a novel is diegetically heard speaking in his or her own voice, there is always a framing voice or consciousness acting as a kind of chorus through which the reader's impressions of him or her are filtered. As Marlow observes, "[Jim] existed for me, and after all it is only through me that he exists for you. I've led him out by the hand; I've paraded him before you" ( $L J 172$ ). Thus, in self-consciously employing the narrator as a chorus-like mediator between protagonist and reader in Lord Jim, Conrad proposes even more explicitly than Sophocles that identity is neither self-evident nor essential, but a poetic construct brought into being by the act of reading. This act which depends on finding les mots justes, "fit words" (LJ 320) to describe the other can either be private as in a novel or public as in the performance of a tragedy, but it is always more or less contingent. Jim is therefore "one of us" because we are all under the same "cloud" of a subjectivity that consists of precarious negotiations between inner and outer, private and public, imagination and fact. Moreover, others may be mere objects to us, but we as both subjects and objects in/to ourselves may see ourselves no clearer than others do. As Marlow remarks of Jim, "He was not - if I may say so - clear to me. He was not clear. And there is a suspicion he was not clear to himself either" $(L J 135) .{ }^{9}$

\footnotetext{
${ }^{9}$ Joanne Wood has observed that "The central concern of [Lord Jim] is the moral ambiguity that results from our common obscurity of vision into ourselves and those around us." "Lord Jim and the Consequences of Kantian Autonomy," Philosophy and Literature 1987, vol. 11(1), p. 57.
} 
III

According to Hegel's influential theory of tragedy, the moral claim which the tragic hero upholds to the point of death-in Antigone's case, it is the determination to do her duty by her dead brother come what may — is misguided only in being absolute, while the hero's hamartia, or tragic flaw, ${ }^{10}$ resides in his or her inability to see that competing moral claims are equally valid. ${ }^{11}$ This theory can be applied to all the works we have looked at so far, but it is also particularly useful in understanding the next tragedy on our list which makes use of the clouded-sky motif, Euripides' Hippolytus. Euripides is the most modern of the classical trio of tragedians in outlook and style, emphasizing in his plays not so much the traditional subject of tragedy, the power of divine law, but human nature in all its flaws and contradictions. His iconoclastic dramaturgical technique that seems to neglect the gods in a genre that was traditionally religious was noted even in his own day, prompting Aristotle to famously observe that Sophocles presents people "as they should be," but Euripides presents them "as they are" (Poetics 1460b). Another element which connects Euripides to the modernist author of Lord Jim is the former's close familiarity with and literary use of the philosophical currents of his day, particularly the work of the sophists Anaxagoras, Protagoras, and Gorgias (Davie xxxix) who, among other things, taught moral and ontological relativism: a subject close to Conrad's heart.

In the Hippolytus, Euripides rewrites the myth of Phaedra who fell passionately in love with her son in law, but was scorned by him and eventually took her own life. The tragedy bears the young man's name, however, because Hippolytus is finally destroyed by his father's curse after Phaedra falsely accuses him of raping her to preserve her reputation. Although the puritanical Hippolytus is a questionable tragic hero, we clearly have two tragic victims here: the one victim of his moral fastidiousness and the other victim of her passions. As Conrad wrote in "Henry James: An Appreciation" (1905), describing just such a situation: "A man must sacrifice his gods to his passions or his passions to his gods" (NLL 19). In an ideal world, there should have been some via media between Hippolytus' creditable need to maintain his chastity and Phaedra's equally justifiable need to maintain her reputation in the face of her illicit desire, but as Conrad's above statement implies the human condition is ever to be torn between extreme and irreconcilable contradictions. Jim could have been content with the honour that comes from simply performing one's duty in the ranks and Gentleman Brown could have been satisfied with escaping from Patusan

${ }^{10}$ It must be noted that such terms as 'tragic flaw,' or indeed 'tragic hero,' are only approximate renderings of corresponding classical concepts and have more or less been constructed by subsequent scholars rather than merely translated. See J. Jones, Greek Tragedy Reconsidered: On Aristotle and Greek Tragedy, London: Chatto \& Windus, 1962.

${ }^{11}$ A. C. Bradley has summarized Hegel's theory as follows: "It is the nature of the tragic hero, at once his greatness and his doom, that he knows no shrinking or half-heartedness, but identifies himself wholly with the power that moves him, and will admit the justification of no other power. However varied and rich his inner life and character may be, in the conflict it is all concentrated in one point." "Hegel's Theory of Tragedy," Oxford Lectures on Poetry, London: Macmillan, 1909, p. 71. 
with his life if not his pride intact, but as Stein says, "[Man] wants to be a saint, and he wants to be a devil — and every time he shuts his eyes he sees himself as a very fine fellow-so fine as he can never be" (LJ 162).

The danger of moral idealism turning into self-righteousness is marked in both works as is the difficulty of maintaining balance and self-control. As Marlow remarks, Jim's "fine sensibilities" are really "a sort of sublimated idealized selfishness," (LJ 135) while Hippolytus' high moral principles - deified in the play in the figure of Artemis - are so inflexible and unreflective as to resemble the worst passions attributed to the seductress Aphrodite. The prince's devotion to the goddess of chastity is ironically couched in erotic terms, while his repeated boasts of being the purest man alive suggests a narcissistic personality not so different from the "immaculate" Jim, whom "nothing could touch" ( $L J 185)$. As the Chorus reflects after having witnessed Hippolytus' nemesis, "may my thoughts and opinions not be rigid and at the same time false-coined. May my ways be flexible" ( $H$ 165). Nevertheless, passions in their characteristic extremity predominate in the play: Phaedra's obsession with Hippolytus is repeatedly shown overwhelming her good resolutions, while Theseus' rage upon reading his wife's accusations against his son does not allow him a moment's pause before he condemns the latter to death. The power of subconscious forces in the personality to overturn moral intent and undermine self-possession is something that Jim also becomes painfully aware after his jump. As Euripides' choragos observes in a way that could serve as a fitting epitaph for Jim, "Ah, what a fine thing it is to have self-discipline in all circumstances!" (H 148)

In the Hippolytus, the clouded-sky motif accompanies the love-sick Phaedra's first entrance. Again, the relevant passage is spoken by the Chorus:

But lo! The aged nurse at the gates

Leads out the queen, on whose downcast brow

Care spreads a deeper cloud.

Fain would I know what grief

Preys in secret on her faded charms.

(H 171-175, my translation)

Like Jim, who is described superficially by the omniscient narrator for several chapters before appearing in person, through Marlow's more subjective narrative, Phaedra comes on stage only after lengthy third-person exposition, of which this passage forms an integral part. It is as if both writers want to shield their shame-ridden characters from view for as long as possible, not only to produce suspense, but also to imply that they are concealing a secret dangerous for the community. The image of love as a hidden malignant growth in the last line is strikingly reminiscent of William Blake's conceit in "The Sick Rose" (1794) in which the "dark secret love" of the "invisible worm" is said to destroy the life of the lover. However, the natural curiosity expressed in the Chorus' desire to know what the clouds of grief obscure will only bring suffering and tragedy to all involved.

As with the conceptual antithesis between Ismene and Antigone in Sophocles' tragedy, the aged Nurse functions as a dramatic foil for the young queen in the Hippolytus, espousing a low-born pragmatism that strongly contrasts with Phaedra's 
noble determination to preserve her reputation at all costs. By dismissing Phaedra's moral qualms with the phrase: "If anything more precious than life does exist, it's wrapped in darkness, hidden behind clouds... silly stories" (H 141-42), the Nurse can be said to express the equivalent of Chester's cynical world-view which equated honour with "a piece of ass's skin" ( $L J 137)$ not worth the bother. The implication of such claims is that what is hidden from view but is taken as more significant than the visible - i.e. the metaphysical which also includes the ethical — may be no more than an imaginary projection, hence the equation of idealism with illusion often found in Conrad' work. Reminiscent of Marlow who takes "professional opinion" ( $L J 112$ ) on under-the-weather Jim from a variety of experts, the Nurse will propose that her ailing charge confide in the female Chorus, or, alternatively "if men can be told of your ailment, out with it and we'll consult doctors" (H 144). However, like the French Lieutenant's counsel in Lord Jim, the Chorus' advice on Phaedra's problem is too idealistic in over-emphasizing the side of self-discipline and honour. The Nurse, on the other hand, adopts the opposite position and advises Phaedra to succumb to her desires and stay alive, rather than "bask in [her] good name and die" ( $H$ 148). But neither idealism nor expediency can offer any remedy for Phaedra's all-too-human condition. The Nurse will eventually destroy the queen by taking matters into her own hands and revealing the secret to Hippolytus, just like Marlow who, in seeking to give Jim hope and alleviate his suffering, sets a chain of events in motion which ends with the renegade's tragic demise.

The clouded-sky motif, in the Hippolytus but also in the other tragedies we have explored, emphasizes the fact that the human psyche is opaque and inaccessible from without. As Andrew Gibson observes, the other "is always radically in excess of what my ego, cognitive powers, consciousness or intuitions would make of her or him. The other always and definitively overflows the frame in which I would seek to enclose the other" (25). This may be a blessing in disguise since, notwithstanding the scapegoat-producing fissures that accompany the subject viewed as object, there may be more danger in being understood than in being misunderstood. As the Chorus says to Phaedra upon the latter's disclosing her secret to the Nurse, "You're ruined! You have exposed your guilty secret to the light" ( $H$ 146). Like the veil over the proverbial Eastern bride's face which conceals the fact that Jim's enticing opportunity is synonymous with his doom, Phaedra's clouded visage seems in hindsight to have been preferable to a clear view of her face, which she imagines being revealed in the metaphorical mirror of Time ( $H$ 148). Reflecting the tragic genre's anti-gnostic pessimism, Artemis appears ex machina at the end of the Hippolytus and says to Theseus: "I came here to reveal your son's righteous heart so he may die with untarnished name... It will remedy nothing but it will cause you pain" (H 169). Similarly in Lord Jim, Marlow's sustained efforts to lift the moral and ontological fog from the protagonist, however successful or sincere they may be, cannot ultimately exorcise "from the house of life the haunting shadow of fate" ( $L J 135)$. The glory of the white lord's reign in Patusan is finally little more than a brief respite from that destiny which is said to be "graven in imperishable characters upon the face of a rock" ( $L J 142$ ) and this because, for Conrad as for the ancient tragedians, knowledge cannot 
"us from being ourselves cure" (LJ 162). Thus, Oedipus' lesson is repeated and Jim's clouded countenance - akin to a mask shielding an actor's face from himself as much as from the audience - is presented as humanity's last line of defense against the tragic realization that we are "not strong," or "clever enough" ( $L J 163)$ to realize our dream. In this, as in many other respects, Jim is "one of us."

\section{WORKS CITED}

Ambrosini, R., "Tragic Adventures: Conrad's and Marlow's Conflicting Narratives in Lord Jim," The Conradian 2013, vol. 38(1), pp. 53-71.

Aristotle, Poetics, translated with an introduction and notes by M. Heath. London: Penguin Books, 1996.

Blake, W., Songs of Innocence and Experience: Shewing the Two Contrary States of the Human Soul, 1789-1794, ed. Sir Geoffrey Keynes, Oxford: Oxford UP, 1977.

Bowers, T., "Conrad's Aeneid: Heart of Darkness and the Classical Epic," Conradiana 2006, vol. 38(2), pp. 115-142.

Bradley, A. C., "Hegel's Theory of Tragedy" [in:] Oxford Lectures on Poetry, London: Macmillan, 1909, pp. 69-95.

Conrad, J., Lord Jim: A Tale (1900), edited with an introduction by A. H. Simmons, with notes and glossaries by J. H. Stape, Penguin Classics, London: Penguin, 2007.

---------, Notes on Life and Letters (1921), eds. J. Stape, A. Busza. Cambridge: Cambridge UP, 2004.

Deresiewicz, W., "Lord Jim and the Transformation of Community," Raritan 2000, vol. 20(2), pp. 71-105.

Euripides, Medea and Other Plays (1996), transl. J. Davie, with an introduction and notes by J. Rutherford, Penguin Classics, London: Penguin Books, 2003.

Gibson, A., Postmodernity, Ethics, and the Novel: From Leavis to Levinas, Routledge: London, 1999.

Homer, The Iliad, transl. P. Jones, D. C. H. Rieu, with an introduction and notes by P. Jones, London: Penguin, 2003.

Jones, J., Greek Tragedy Reconsidered: On Aristotle and Greek Tragedy, London: Chatto \& Windus, 1962.

Liddell, H. G., Scott, R., A Greek-English Lexicon: A Supplement, $9^{\text {th }}$ Edition, eds. E. A. Barker et al., Oxford: Oxford UP, 1968.

Najder, Z., "Lord Jim: a romantic tragedy of honour" [in:] idem, Conrad in Perspective: Essays on Art and Fidelity, Cambridge: Cambridge UP, 1997.

Panagopoulos, N., "Conrad's Poetics: An Aristotelian Reading of Heart of Darkness," L'Epoque Conradienne 2015-2016, vol. 40, pp. 117-149.

Ray, S., “Marlow(e)'s Africa: Postcolonial Queenship in Conrad's Heart of Darkness and Marlowe's Dido, Queen of Carthage," Conradiana 2006, vol. 38(2), pp. 143-161.

Said, E., Orientalism (1978), Penguin Classics, London: Penguin, 2003.

Smead, M. J., The Antigone of Sophocles. The Greek Text Revised and Corrected, with an Introduction and Critical and Explanatory Notes, for the Use of Academics and Colleges, New York: Appleton \& Co., 1871.

Sophocles, Antigone, ed. M. Griffith, Cambridge Greek and Latin Classics, Cambridge: Cambridge UP, 1999. 